\title{
Chronology of COVID-19 Pandemic - the Un-flatten Curve
}

\author{
${ }^{a *}$ Mohd Aleemuddin Qumari, ${ }^{b}$ Farooqui Shazia Parveen, ${ }^{c}$ Md Anzar Alam, ${ }^{\mathrm{d}}$ Mariyam Ahad \\ aProfessor, Head of the Department-Medicine, National Institute of Unani Medicine, India. \\ bPh.D Research Scholar, Department of Medicine, National Institute of Unani Medicine, India. \\ 'Lecturer, Department of Medicine, National Institute of Unani Medicine, India. \\ ${ }^{d}$ PG Scholar, Department of Medicine, National Institute of Unani Medicine, India \\ Email: drmaquamri@gmail.com, Contact no.: 9341072974
}

\begin{abstract}
The COVID-19 pandemic gripped 193 countries including certain territories, though the disease started in Wuhan city China on $17^{\text {th }}$ November 2019 as pneumonia of unknown origin linked to its seafood market, the China health authorities reported it as on $31^{\text {st }}$ December 2019. The coronavirus responsible for the disease is a novel stain observed in human is a spill-over from animals seems to be bats with $96 \%$ genomic resemblance indicative of an intermediary host a mammal till not known. Initially, it has considered as human-to-human transmission of infection through contact, later hypothesizing the spread through aerosol infection also. The uncertainty with the disease has little compared with past influenza as if conditions but most of the things associates with this are unpredictable. Now, more than 2 million cases found positive with $\mathbf{2 . 5}$ lac cases of death around the world still it is on with meagre recovery rate. The course diseases and its management become a big task for the entire globe. The entire globe is finding the solutions with historical observations and experience, including the use of antiviral, antibiotics, and anti-malarial drugs and plasma convalescent therapy beyond these placenta proteins cells, and mesenchymal stem cell therapy are being under exploration as effective means in the management of COIVD-19.
\end{abstract}

Key words: Chronology of COVID-19; Pandemic; Influenza like conditions; Unflatten Curve.

\section{Introduction}

The COVID-19 infection is a pandemic caused by a novel coronavirus a new strain of the virus in humans belongs to the beta coronovirdea family; basically, it affects the lungs and causes severe acute respiratory symptoms, and the virus hosts ACE2 receptors in the lungs and other parts of the body including kidney [1,2]. The first confirmed case was date back to $17^{\text {th }}$ November 2019, and reported by the China National Health commission to WHO as $31^{\text {st }}$ December, 2019[3]. Initially the infection was thought to be transmitted from Wuhan seafood-wet market in China, later learned that human to human contact and cluster transmission is reported, moreover, hypothesizing that aerosol infection may likely to be possible among the peoples closely associated with the infected person including health care workers(HCE)[4]. The symptoms of COVID-19 may range from mild, moderate to severe; around 86 percent of cases usually reported moderate symptoms of fever, dry cough, sore throat and diarrhoea, and among severely infected cases respiratory and multi-organ failure[5]. Then incubation period was assumed to be 14 days, later found it as 27 days with the viability of virus for five weeks[6]. The management of infection with the antiviral and antibiotic not proved to be effective[7]. As of $21^{\text {st }}$ April 2020, globally there have been 2397216 confirmed cases with 162956 deaths with COVID-19, out of this America reported the highest number of cases 751273 followed by Spain (200210), Italy (181228), Germany (143457), France (113513), the United Kingdom (124747), Turkey (90980), and Iran (83505), and the fatality reported in orderly higher in France (113513 with 17.82\%), followed by United Kingdom (16509 with 13.23\%), Italy (24114 with $13.31 \%$ ), Spain ((200210 with $10.01 \%)$ Iran (5209 with $6.24 \%$ ), America (35884 with $4.78 \%$ ), Germany (4598 with $3.21 \%$ ), and Turkey (2140 with $2.35 \%$ ) with meagre recovery rates[8]. This paper is an effort to update and order the events of this infection-related to chronology.

1.1. Chronology of COVID-19:

On $8^{\text {th }}$ December 2019, the first patient with the onset of symptoms of pneumonia has reported by WHO[9]. The epidemic Severe Acute Respiratory Infection (Pneumonia like) was observed from December $12^{\text {th }}, 2019$ in Wuhan city of China[10]. According to Daniel Lucey, Georgetown University the first reported case emerged on $1^{\text {st }}$ December 2019; it is possible that the initial human infection took place in November 2019 if not earlier[11,12]. On 12th December 2019, Wuhan Municipal Health Commission (WMHC) reported cases_of unexplained pneumonia with the recent history of exposure to wildlife animals at the Huanan Seafood Wholesale Market in Wuhan, China, where many wild animals such as hedgehog, badger, snake, poultry, bats, birds, and other farm animals were also sold for human consumption [13]. 
On $2^{\text {th }}$ December 2019, four more cases of unidentified pneumonia were linked to the Huanan, Southern China Seafood Wholesale Market, Wuhan city, Hubei province of Central China, and were picked up by local healthcare facilities running the surveillance program for 'pneumonia of unknown aetiology[14,15].

On 30 ${ }^{\text {th }}$ December 2019, the Wuhan municipal health service sent out an alert that a cluster of 27 cases of pneumonia of unknown origin with 7 severe cases reported from Wuhan of Hubei provinces in central China to its National Health Commission (WHO) [16,17].

Health care workers notice a pattern of illness they had never seen before among the population, common symptoms include fever, body aches, tiredness, and difficulty breathing [18,19]. Dr. Li Wenliang an ophthalmologist at Wuhan Central Hospital one of the health facilities at the epicenter of the epidemic sent a message to a group of fellow doctors warning them about the seven severe cases as the possible outbreak of an illness that resembled severe acute respiratory syndrome (SARS) in Wuhan, Hubei province, China, he encouraged them to protect themselves from infection [20,21, 22.].

On 31 ${ }^{\text {st }}$ December 2019 the Peoples Republic China under its obligations for International Health Regulations (2005), [23] reported to the World Health Organization (WHO) China bureau in Beijing 27 cases with pneumonia of unknown aetiology had taken place, out of which 7 cases are severely ill and the remaining are stable, with the clinical features common to several infectious respiratory diseases such as fever, dyspnoea, and bilateral lung infiltrates on chest radiographs[24, 25].

Soon, the disease spread rapidly within and outside the Hubei Province and engulfed a large number of countries initially to Thailand, Japan, and the Republic of Korea[26]. The Outbreaks and clusters of the disease have since been observed in Asia, Europe, Australia, Africa, and the Americas[27,28].

Since the cause was unknown at the onset of these emerging infections, the diagnosis of pneumonia of unknown cause was based on clinical characteristics, chest imaging, and the ruling out of common bacterial and viral pathogens that cause pneumonia[29]. Suspected cases were isolated using airborne precautions in the designated hospital, Jin Yintan Hospital (Wuhan, China)[30].

Chines health authorities placed all suspected cases of Wuhan under isolation at Jin Yintan Hospital and initiated contact tracing activities and applied hygiene and environmental sanitation activities at the market, which was closed to the public on $\mathbf{1}^{\text {st }} \mathbf{J a n u a r y} \mathbf{2 0 2 0}[31,32,33,34]$.

Preliminary investigations suggested a diagnosis of viral pneumonia and reported no significant human-tohuman transmission and no cases among healthcare workers[35,36].

On 2 January 2020, the incident management system was activated across the three levels of WHO (country office, regional office, and headquarters) by the WHO [37, 38].

On $5^{\text {th }}$ January 2020, an additional of 32 cases of pneumonia reported in Wuhan city with dates of onset falls from $1^{\text {th }}-2^{\text {th }}$ December 2019, raising the total number of reported pneumonia cases of unknown aetiology to $59[39,40]$. Samples of Broncho-alveolar lavage fluid (BALF) from the patients with severe pneumonia was sent to Wuhan Institute of Virology (WIV) for the diagnosis of the causative pathogen [41, 42].

On $7^{\text {th }}$ January 2020, Zheng-Li Shi a Chinese scientist and virologist of Wuhan Institute of Virology based on the meta-genomic RNA sequencing of a sample of Broncho-alveolar lavage fluid from the patient identified a new RNA virus strain and named it as 'novel coronavirus [43].

The genomic sequence of the virus was $96 \%$ identical to that of a Severe Acute Respiratory Syndrome coronavirus (SARS-CoV) identified in horseshoe bats in Yunnan. Zhou et al. found that the genome sequence results suggested that bat species might be a host i.e., the natural reservoir of SARS-CoV [44].

On $\mathbf{8}^{\text {th }}$ January 2020, first confirm case is reported in Thailand [45].

On $9^{\text {th }}$ January 2020, the Chinese Centre for Disease Control and Prevention (CDC) ruled out SARS-Cov and MERS-CoV and confirmed that a novel coronavirus $(2019-\mathrm{nCoV})$ had been detected as the causative agent of pneumonia $[46,47]$.

On $\mathbf{1 0}^{\text {th }}$ January 2020, the novel coronavirus genome sequence was made publicly available by the Shanghai Public Health Clinical Centre \& School of Public Health, in collaboration with the Central Hospital of Wuhan, Huazhong University of Science and Technology, the Wuhan Centre for Disease Control and Prevention, the National Institute for Communicable Disease Control and Prevention, the Chinese Centre for Disease Control, and the University of Sydney, Australia [48, 49]. The sequence was deposited in the Gene Bank database (accession number MN908947), and was uploaded to the Global Initiative on Sharing all Influenza Data (GISAID). Preliminary analysis showed that the novel coronavirus clusters with the SARS-related CoV clade and differs from the core genome of known bat $\mathrm{CoV}[50,51]$.

Preliminary analyses indicate that 2019-nCoV has some amino acid homology to SARS-CoV and may be able to use ACE2 as a receptor. This has important implications for predicting pandemic potential moving forward [52]. 
On $11^{\text {th }}$ January 2020, China has reported a first fatal case of the novel coronavirus [53].

On $12^{\text {th }}$ January 2020, Novel coronavirus $(2019-n C o V)$ was named temporarily by the WHO [54, 55]. On $13^{\text {th }}$ January 2020, first confirmed case is reported in Nepal [56] and on $14^{\text {th }}$ January in Japan [57].

On 15 January 2020, WHO Developed the surveillance case definitions for human infection with 2019-nCoV and the Ministry of Health, Labour and Welfare, Japan (MHLW) reported an imported case of laboratoryconfirmed 2019-novel coronavirus (2019-nCoV) from Wuhan, Hubei Province, China [58].

On $\mathbf{1 7}^{\text {th }}$ January 2020, WHO published an updated of the interim guidelines for the laboratory testing of a novel coronavirus, 2019 [59]. Up to $17^{\text {th }}$ January 2020, 44 laboratory-confirmed cases of viral pneumonia have been reported, with the onset of symptoms ranged from $8^{\text {th }}$ December 2019 to $5^{\text {th }}$ January 2020 [60].

On $\mathbf{1 9}^{\text {th }}$ January 2020, first confirmed case is reported in the Republic of Korea [61] and on $20^{\text {th }}$ January 2020 in USA. The coronavirus infection has classified as fortifiable infectious diseases in China [62]. Furthermore, The Lancet-recently documented infections in health-care workers caring for patients with 2019-nCoV indicate human-to-human transmission and thus the risk of a much wider spread of the disease [63].

On 21st January 2020, WHO reported 314 confirmed cases of novel coronavirus (2019-nCoV) globally; out of these deaths of 6 cases from Wuhan; and 16 infected case health care workers (HCW) [64].

On $\mathbf{2 2}^{\text {th }} \boldsymbol{\& 2 3}^{\text {rd }}$ January 2020 WHO called for the $1^{\text {st }}$ emergency meeting, and later declared that the infection in health care workers (HCWs) caring 2019-nCov patients were reported and the same is being confirmed by China as human to human transmission of the virus (WHO) [65]. It is also supported by the article published in NEJM that the human to human transmission of 2019-nCoV was demonstrated [66].

A Familial Cluster of Infection Associated With the 2019 Novel Coronavirus Indicating Possible Person-toPerson Transmission during the Incubation Period [67]. On 23 ${ }^{\text {rd }}$ January 2020, first confirm case is reported in Singapore[68] and WHO reported $25 \%$ of confirmed cases are severely and critically ill as classified by the Chinese health authorities[69] The initial source of infection remains unknown. However, the outbreak is no longer due to the exposures at the Huanan seafood market in Wuhan. There is now more evidence that the spread of infection is from human- to- human, moreover, family clusters involving persons with no reported travel to Wuhan[70].

On $2^{\text {th }}$ January 2020, first confirm case are reported in France and Vietnam, and China published the first clinical data from individuals confirmed to be infected with 2019-nCoV from Wuhan, China [71]. Chaolin Huang and colleagues provide comprehensive findings for the first 41 laboratory confirmed cases, 27 of these 41 cases had direct exposure to the Wuhan seafood market that has thought to be the initial site of infection from an animal source [72]. All had viral pneumonia, the severity of illness is concerning: almost a third of patients developed acute respiratory distress syndrome requiring intensive care; six patients died; five had an acute cardiac injury, and four required ventilation [73].

First confirmed cases of COVID-19 infection are reported during January, 2020 in countries like Australia and Malaysia on $25^{\text {th }}$ January,[72] Canada on $26^{\text {th }}$ January[75], Cambodia and Sri Lanka on 27 ${ }^{\text {th }}$ January[76] Germany on $28^{\text {th }}$ January[77], UAE, Finland and Italy on $29^{\text {th }}$ January[78].

On $3^{\text {th }}$ January 2020, WHO in its $2^{\text {nd }}$ emergency meeting declared that the outbreak of 2019-nCoV infection has become Public Health Emergency of International Concern (PHEIC), [79] and first confirmed case are reported in India and Philippines[80]. In India the first confirm case was reported from Kerala state, with two more subsequent cases reported, all the three cases had recent travel history from Chinas Wuhan city[81].

On $3^{\text {st }}$ January 2020 first confirmed is case reported in Russia Federation, Spain, Sweden and UK [82]

On $1^{\text {st }}$ February 2020, WHO published by PAHO laboratory guidelines for detection and diagnosis of the novel coronavirus, 2019 [83]. A cluster of Indexed cases on Princess Diamond cruise ship have been confirmed in Hong Kong with SARI cases [84].

On $2^{\text {nd }}$ February 2020 first fatal case was reported outside China (WHO) [85].

On $4^{\text {th }}$ February 2020 first confirmed case was reported in Belgium [86].

On $11^{\text {th }}$ February 2020, an International Committee on Taxonomy of Viruses (ICTV) WHO declared that the 2019-nCoV was officially names as "Severe Acute Respiratory Syndrome Coronavirus 2 (SARS-CoV-2) [87]. This name was chosen because the virus is genetically related to the coronavirus responsible for the SARS outbreak of 2003 [88]. The pneumonia infected with 2019-nCoV was officially named as COVID-19 by WHO $[89,90]$.

On $1^{\text {th }}$ February 2020, first confirmed case reported in Egypt, on $20^{\text {th }}$ February in Iran, on $22^{\text {nd }}$ February in Lebanon and Israel, on $24^{\text {th }}$ February in Kuwait [91], on $25^{\text {th }}$ February in Afghanistan, Bahrain, Oman, and Iraq, on $26^{\text {th }}$ February in Austria, Switzerland, Algeria and Croatia, on $27^{\text {th }}$ February in Brazil, Denmark, Estonia, Georgia, Greece, Norway, Pakistan, Romania, and North Macedonia, on $28^{\text {th }}$ February in Belarus, Netherlands, New Zealand, and Nigeria, on 29th February in Mexico, and San Marino [92]. COVID-19 stands for 
coronavirus diseases of 2019 and is a respiratory infection caused by the novel coronavirus SARS-CoV-2 [93]. The term novel coronavirus means that a new type of coronavirus that has crown-like spikes around it. Here corona stands for crown in latin [94].

Coronaviruses (CoVs) are enveloped non-segmented positive-sense RNA viruses, which are of roughly $30 \mathrm{~kb}$ genome surrounded by protein belonging to the family Coronaviridae and the order Nidovirales, and are broadly distributed in humans and other mammals [95]. First discovered in domestic poultry in 1965s and causes a range of respiratory, gastrointestinal, hepatic, and neurologic diseases in animal, Scientists first discovered that CoV originate among bats following the outbreak of Severe Acute Respiratory Syndrome (SARS) in 2003 [96]. $\mathrm{CoV}$ are zoonotic viruses- that can spill-over from animals to humans [97]. As the coronavirus family grows, different strains simultaneously co-infect individual bats, turning their little bodies into virus blenders, creating new strains of every sort, some more powerful than others [98].

This process happens without making bats sick - a phenomenon that scientists have linked to bats' singular ability, among mammals, to fly [99]. The feat takes a severe toll, such that their immune systems have evolved a better way to repair cell damage and to fight off viruses without provoking further inflammation [100]. But when these viruses leap into a new species - whether a pangolin or a civet or a human - the result can be severe, sometimes deadly, sickness [101].

In 2013 Shi Zheng-Li sequenced a coronavirus found in bats, which, in January, she discovered shares $96 \%$ of its genome with SARS-CoV-2 [102]. The two viruses have a common ancestor that dates back 30 to 50 years, but the absence of a perfect match suggests that further mutation took place in other bat colonies, and then in an intermediate host [103]. Analyses of the SARS-CoV-2 genome indicate a single spill-over an event, meaning the virus jumped only once from an animal to a human, which makes it likely that the virus was circulating among people before December 2019 [104].

Researchers from South China Agricultural University declared the intermediate host of SARS-CoV-2 could be the Chinese pangolin (Manis pentadactyla) although this has not been confirmed at this date [105].

The new coronavirus is an elusive killer since people have never seen this strain before; there is much about it remains mystery [106]. Till date seven coronaviruses are known to cause disease in humans; four cause symptoms of the common cold are 229E, OC43, NL63, and HUK1, and the other three cause more serious lung infections including pneumonia are SARS-CoV (Severe Acute Respiratory Syndrome (SARS) and MERS-CoV in 2012 (Middle East Respiratory Syndrome or MERS) and SARS-CoV-2 (the current pandemic known as COVID-19) [107].

The SARS-CoV-2 is a genus Beta-coronavirus, subgenus Sarbecovirus belonging to the family of Coronaviridae [108]. Essentially a zoonotic disease, the first human coronavirus outbreak was recorded in 1965 - HCoV-229E, followed by two outbreaks of similar capacity - SARS-CoV and MERS-CoV in 2003 and 2012 , respectively $[109,110]$.

On 1st March 2020, first confirmed case is reported in Ireland, Monaco, Qatar, Azerbaijan, Ecuador, On 2nd March in Armenia, Czechia, Dominica Republic Luxembourg, Iceland, and Indonesia, On 3rd March in Andorra, Jordan, Latimia, Morocco, Portugal, Saudi Arabia, Senegal, and Tunisia, on 4th March in Argentina, Chile, Poland, and Ukraine, on 5th March in Bosnia, Herzegovina, Gibraltar, Hungary, Slovenia, Palestinian territory, on 6th March on Bhutan, Cameroon, Serbia, and South Africa, on 7th March in Colombia, Holy see, Peru, and Togo, on 8th March in Bulgaria, Costa Rica, Faroe Islands, French, Guiana, Maldives, Malta, Martinique, and Republic of Moldova, on 9th March in Bangladesh, Albania, and Paraguay and on 10th March in Brunei Darussalam, Mongolia, Cyprus, and Guernsey, Panama [111, 112].

On 11th March 2020 WHO declared COVID-19 as global pandemic as the virus and the disease spread worldwide and first confirm case is reported in Bolivia, Tamika, Burkina Faso Democratic Republic of Congo[111, 112].

On 12th March, 2020 first confirmed case reported in French Polynesia, Turkey, Honduras, Cote D' Ivories[111, 112].

On 13th March, 2020 WHO updated interim guidelines for laboratory testing for coronavirus in suspected human cases (WHO)., first confirm case is reported in Guyana, Grenadines[111, 112].

On $14^{\text {th }}$ March first confirmed case is reported in Lithuania, Liechtenstein, Puero Rico Venezuela, Antigua, and Barbuda, on $15^{\text {th }}$ March in Cayman Island, Ethiopia, Gabon, Ghana, Guinea, Kenya, Kazakhstan, Curacao, Namibia, Central African Reuchlin, Congo, Equatorial Guinea, Eswatini, Mauritania, Mayotte, on 16th March in Uzbekistan, Uruguay, Rwanda, Seychelles, and Montenegro, on $17^{\text {th }}$ March in Guam Somalia, Bahamas, Aruba, United States Virgin Island Benin, and the United Republic of Tanzania, on $19^{\text {th }}$ March in Kyrgyzstan, Djibouti, Barbados, Montserrat, Mauritius, Zambia, and the Gambia, on $20^{\text {th }}$ March in Fiji, New Caledonia, El Salvador, Nicaragua, Chad, and Niger, on $21^{\text {st }}$ March in Papua New Guinea, Isle of Man, Timor-Leste, Haiti, and Cabo Verde, Zimbabwe, on $22^{\text {nd }}$ March in Madagascar, Angola, Eritrea, and Uganda, on $23^{\text {rd }}$ March in 
Syrian Arab, Republic Grenada, and Mozambique, on $24^{\text {th }}$ March in Myanmar, Belize Dominica, Turks, and Caicos Island, on $25^{\text {th }}$ March in Lao people's Democratic Republic, Libya, on $26^{\text {th }}$ March in Saint Kills and

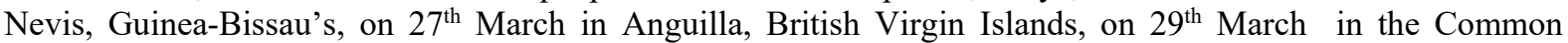
wealth of the Northern Mariana Islands[111, 112].

On $1^{\text {st }}$ April 2020, first confirmed case was reported in Botswana, Burundi, and Sierra Leone, on $3^{\text {rd }}$ April in Malawi, on $4^{\text {th }}$ April in Bonaire, Sint Eustatius Saba, on $5^{\text {th }}$ April in Falkland Islands (Malvinas), on $6^{\text {th }}$ April in South Sudan, on $7^{\text {th }}$ April in Sao Tome and Principe, on $8^{\text {th }}$ April in Saint Pierre and Miquelon, on $11^{\text {th }}$ April in Yemen $[111,112]$.

\subsection{SARS-CoV-2 Natural / Laboratory created:}

Some folks claim that the new coronavirus causing the pandemic was man-made or engineered in a lab and deliberately released to make people sick [113]. It is currently impossible to prove or disprove the theories of its origin [114]. However, since we observed the result of genomic features might explain in part the infectiousness and transmissibility of SARS-CoV-2 in humans and it discredits that this novel coronavirus arose naturally $[115,116]$.

China blaming as the US army may have brought the virus to Wuhan: China [117]. Luc Montagnier a Noble Laureate and French virologist has claimed that SARS-CoV-2 is man-made virus and as an industrial accident was said to have taken place in the Wuhan National Biosafety laboratory that specializes in these coronaviruses since the early 2000s [118].

\section{Incubation Period:}

The incubation period was 27 days [119,120,121].

\section{Transmission of infection:}

COVID-19 virus is primarily transmitted between people through respiratory droplets and contact routes (primarily contact with an infected person, or indirectly with surfaces in the immediate environments i.e., fomites (objects used on by the infected person). Initially, airborne transmission was not considered as mean for infection [122]. But, the possibility of transmission can't be ruled out under specific circumstances and settings in which procedures or support treatments that generate aerosols are performed; i.e., endotracheal intubation, bronchoscopy, open suctioning, administration of nebulized treatment, manual ventilation before intubation, turning the patient to the prone position, disconnecting the patient from the ventilator, non-invasive positivepressure ventilation, tracheostomy, and cardiopulmonary resuscitation[123]. Current research supports the possibility of spread of infection through bio-aerosols generated directly by patients' exhalation, they are referring to fine particles emitted when someone breathes that can be suspended in the air [124].

According to Linsey Marr, an aerosol scientist at Virginia Tech the health experts so far less paid importance to the possibility of transmitting covid19 infection through the air, "I think that transmission by inhalation of the virus in the air is happening, Scientists Probe How Coronavirus Might Travel Through The Air, National Research Council 2020 [125].

Since the study indicates that the aerosol and fomite transmission of SARS-CoV-2 is plausible since the virus can remain viable and infectious in aerosols for hours and on surfaces up to days (depending on the inoculum shed) $[126,127]$. SARS-CoV-2 are viable and detected up to 72 hours (3 days) on the surfaces with a median half-life of approximately 1.1 to 1.2 hours, and the longevity of viability was stable on plastic and stainless steel than on copper and cardboard [128].

\section{Clinical presentation of COVID-19}

However, COVID-19 is a respiratory illness that primarily affects lungs, and researchers reported that the virus is also damaging the Brian, heart, kidneys, intestinal tract and liver [129,130,131]. The range of organs impacted by the virus makes the progression of the disease unpredictable and further complicates the recovery process $[132,133]$.

About $80-85 \%$ of patients suffer from mild or moderate symptoms, $15-20 \%$ of cases experience severe $[134,135]$. Usually it can take up to six weeks to fully recover from COVID-19, experts say, and even months in some severe cases $[136,137]$.

The most common symptoms manifested are Fever, Fatigue, Dry cough, Anorexia, Myalgia, Dyspnoea, Sputum, and Sore throat,[ 138,139,140] Uncommon symptoms are-Confusion, Dizziness, Headache, Running nose, Haemoptysis, Foot sores, Impairment of Renal function otherwise renal failure, Myocarditis, arrhythmia, cardiac arrest, Pulmonary embolism, respiratory failure, Loss of smell and taste (olfactory and gustatory sense), Conjunctivitis, Intestinal infection leads to pain abdomen, diarrhoea and vomiting, Acute inflammation of the liver [141,142,143,144]. 


\section{Placentas cell therapy for COVID19}

On $7^{\text {th }}$ April 2020, according to Yaky Yanay the CEO and President of Pluristem Therapeutics Company Haifa Israel, so far they have treated 7 cases of COVID19 from Israel, and one is under treatment from America with 15-milliliter inter muscular doses of placentas protein known as PLacental eXpanded(PLX) cells [145,146]. All seven Israelis patients had survived and three soon move off ventilators, while one had shown deterioration in respiratory parameters [147]. Two of the four Israelis with multiple organ failure showed clinical recovery as well as respiratory improvement. The firm had obtained approval on a patient-by-patient basis form the regulators [148]. Researchers around the world are studying the efficacy of mesenchymal stem cell-based products and therapy, around 10 patients in China were tested and 7 shows improvement in COVID-19 infection [149].

As the whole world puts up a collective fight against the COVID-19 pandemic, some worrying news has cropped up from across Asia-patients who tested negative of the disease are being infected with the SARS-CoV2 virus again. Such cases had been reported from South Korea, China and Japan. Researchers from China addressed the possibility of reinfection by conducting experiments on rhesus monkeys. After 28 days, they found that the oral and anal swabs of monkeys did not show the presence of the virus. Researchers at the School of Basic Medical Sciences, Fudan University, Shanghai studied blood samples from patients who had been released after treatment and found that nearly a third had low levels of antibodies. In some patients, the antibodies could not be detected at all. The titres (concentration) of antibodies varied according to age. Older patients had more antibodies than the younger ones. The study was published in medRxiv on March 30, 2020 and has not been peer-reviewed. This could mean that if the real virus cannot induce an antibody response, the weakened version used in a vaccine may not work. South Korea's Centre for Disease Control (CDC) claimed the virus reactivated in some patients. It said it would study this further.

"The most likely explanation is that people have simmering virus replication for an unusually long time and this can occasionally result in late reactivation. Most available data stated that the length of virus detection varies from person to person, so it isn't surprising that some people might continue to produce the virus and get sick," says Dave O' Connor, professor at the Department of Pathology and Laboratory Medicine, University of Wisconsin-Madison [150]. The latest news by Italian scientists on 06 May 2020, who claimed to have developed vaccine that neutralises coronavirus in human cells. As per tests conducted at Rome's infectious-disease Spallanzani Hospital, the coronavirus vaccine has antibodies generated in mice that work on human cells. All of the vaccine candidates currently being developed are based on the genetic material of DNA protein 'spike' [151]. Scientists from the University of Texas (UT) at Austin, the National Institutes of Health and Ghent University in Belgium developed a treatment that links two nanobodies isolated from a llama to create an antibody that binds to the spike protein on the coronavirus that causes COVID-19. That bond prevented the virus from invading cells, the researchers reported in the journal Cell [152]. The journal Science on April 26 reported on a clinical trial in which critically ill Covid-19 patients at Northwell Health in the New York City area were receiving nine times the heartburn dose. Interim results from 391 patients could be known in "a few weeks," according to a hospital researcher [153].

\section{Conclusion}

The coronavirus infection is a global threat, still uncertain about its intermediary host and hypothesizing different means of transmission of infection including clusters. The new strain of virus and non-availability of treatment and severely ill and critically ill case management becomes a challenge and novel interventions are under trials. As the pandemic is progressing and the number of deaths is high and recovery is negligible, hence the circumstances prevail compulsory for social distancing and lockdowns.

\section{References:}

[1] Ranscombe P. Rural areas at risk during COVID-19 pandemic. The Lancet Infectious Diseases. 2020 Apr 17. DOI:https://doi.org/10.1016/S1473-3099(20)30301-7.

[2] Shereen MA, Khan S, Kazmi A, Bashir N, Siddique R. COVID-19 infection: origin, transmission, and characteristics of human coronaviruses. Journal of Advanced Research. 2020;24:91-98. https://doi.org/10.1016/j.jare.2020.03.005

[3] First COVID-19 case can be traced back to November 17 in China's Hubei province: Report. https://economictimes.indiatimes.com/news/international/world-news/first-covid-19-case-can-be-traced-back-to-november-2017-inchinas-hubei-province-report/articleshow/74608199.cms?from=mdr.

[4] Xu S, Li Y. Beware of the second wave of COVID-19. The Lancet. 2020 Apr 8. DOI:https://doi.org/10.1016/S0140-6736(20)30845-X.

[5] Liu Y, Yan LM, Wan L, Xiang TX, Le A, Liu JM, Peiris M, Poon LL, Zhang W. Viral dynamics in mild and severe cases of COVID19. The Lancet Infectious Diseases. 2020 Mar 19. DOI:https://doi.org/10.1016/S1473-3099(20)30232-2.

[6] Xiao Y, Torok ME. Taking the right measures to control COVID-19. The Lancet Infectious Diseases. 2020 Mar 5. DOI:https://doi.org/10.1016/S1473-3099(20)30152-3.

[7] Huang C, Wang Y, Li X, Ren L, Zhao J, Hu Y, Zhang L, Fan G, Xu J, Gu X, Cheng Z. Clinical features of patients infected with 2019 novel coronavirus in Wuhan, China. The Lancet. 2020 Feb 15;395(10223):497-506.

[8] COVID-19 World Map: 2,397,216 Confirmed Cases; 207 Countries; 162,956 Deaths. https://scitechdaily.com/covid-19-world-map2397216-confirmed-cases-207-countries-162956-deaths/.

[9] Chen N, Zhou M, Dong X, Qu J, Gong F, Han Y, Qiu Y, Wang J, Liu Y, Wei Y, Yu T. Epidemiological and clinical characteristics of 99 cases of 2019 novel coronavirus pneumonia in Wuhan, China: a descriptive study. The Lancet. 2020 Feb 15;395(10223):507-13. 
[10] Zhou P, Yang XL, Wang XG, Hu B, Zhang L, Zhang W, Si HR, Zhu Y, Li B, Huang CL, Chen HD. Discovery of a novel coronavirus associated with the recent pneumonia outbreak in humans and its potential bat origin. Nature.2020. doi: 10.1038/s41586-020-2012-7.

[11] Cui Y, Tian M, Huang D, Wang X, Huang Y, Fan L, Wang L, Chen Y, Liu W, Zhang K, Wu Y. A 55-Day-Old Female Infant Infected With 2019 Novel Coronavirus Disease: Presenting With Pneumonia, Liver Injury, and Heart Damage. The Journal of infectious diseases. 2020. Mar 17;jiaa113. doi: 10.1093/infdis/jiaa113.

[12] Cheng ZJ, Shan J.2019 Novel coronavirus: where we are and what we know. Infection. 2020 Feb $18: 1-9$.

[13] Cui HT, Li YT, Guo LY, Liu XG, Wang LS, Jia JW, Liao JB, Miao J, Zhang ZY, Wang L, Wang HW. Traditional Chinese medicine for treatment of coronavirus disease 2019: a review. Traditional Medicine Research. 2020 Feb 9;5(2):65-73.

[14] Luo H, Tang QL, Shang YX, Liang SB, Yang M, Robinson N, Liu JP. Can Chinese medicine be used for prevention of corona virus disease 2019 (COVID-19)? A review of historical classics, research evidence and current prevention programs. Chinese journal of integrative medicine. 2020 Feb 17:1-8.

[15] Chan KW, Wong VT, Tang SC. COVID-19: An Update on the Epidemiological, Clinical, Preventive and Therapeutic Evidence and Guidelines of Integrative Chinese-Western Medicine for the Management of 2019 Novel Coronavirus Disease. The American journal of Chinese medicine. 2020 Mar 13:1-26.

[16] Surveillances V. The epidemiological characteristics of an outbreak of 2019 novel coronavirus diseases (COVID-19)-China, 2020. China CDC Weekly. 2020;2(8):113-22.

[17] Mission WC. Report of the WHO-China Joint Mission on Coronavirus Disease 2019 (COVID-19). 2020;(16-24 February).

[18] Surveillances V. The epidemiological characteristics of an outbreak of 2019 novel coronavirus diseases (COVID-19) - China, 2020. China CDC Weekly. 2020;2(8):113-22.

[19] World Health Organization. Coronavirus disease 2019 (COVID-19): situation report, 72.

[20] Reviglio VE, Osaba M, Reviglio V, Chiaradia P, Kuo IC, O’Brien TP. COVID-19 and Ophthalmology: A New Chapter in an Old Story. Medical Hypothesis, Discovery \& Innovation in Ophthalmology. 2020 Mar 4;9(2):71-3.

[21] Petersen E, Hui D, Hamer DH, Blumberg L, Madoff LC, Pollack M, Lee SS, McLellan S, Memish Z, Praharaj I, Wasserman S. Li Wenliang, a face to the frontline healthcare worker. The first doctor to notify the emergence of the SARS-CoV-2,(COVID-19), outbreak. International Journal of Infectious Diseases. 2020 Apr 1;93:205-7.

[22] Xu XW, Wu XX, Jiang XG, Xu KJ, Ying LJ, Ma CL, Li SB, Wang HY, Zhang S, Gao HN, Sheng JF. Clinical findings in a group of patients infected with the 2019 novel coronavirus (SARS-Cov-2) outside of Wuhan, China: retrospective case series. bmj. 2020 Feb $19 ; 368$.

[23] Sohrabi C, Alsafi Z, O’Neill N, Khan M, Kerwan A, Al-Jabir A, Iosifidis C, Agha R. World Health Organization declares global emergency: A review of the 2019 novel coronavirus (COVID-19). International Journal of Surgery. 2020 Feb 26.

[24] Zhou F, Yu T, Du R, Fan G, Liu Y, Liu Z, Xiang J, Wang Y, Song B, Gu X, Guan L. Clinical course and risk factors for mortality of adult inpatients with COVID-19 in Wuhan, China: a retrospective cohort study. The Lancet. 2020 Mar 11.

[25] Zu ZY, Jiang MD, Xu PP, Chen W, Ni QQ, Lu GM, Zhang LJ. Coronavirus disease 2019 (COVID-19): a perspective from China. Radiology. 2020 Feb 21:200490.

[26] Zhao W, Zhong Z, Xie X, Yu Q, Liu J. Relation between chest CT findings and clinical conditions of coronavirus disease (COVID-19) pneumonia: a multicenter study. American Journal of Roentgenology. 2020 Feb 19:1-6.

[27] Tandon PN. COVID-19: Impact on health of people \& wealth of nations.IJMR.2020. DOI: 10.4103/ijmr.IJMR_664_20

[28] Wu YC, Chen CS, Chan YJ. The outbreak of COVID-19: An overview. Journal of the Chinese Medical Association. 2020 Mar $1 ; 83(3): 217-20$

[29] Shi H, Han X, Jiang N, Cao Y, Alwalid O, Gu J, Fan Y, Zheng C. Radiological findings from 81 patients with COVID-19 pneumonia in Wuhan, China: a descriptive study. The Lancet Infectious Diseases. 2020 Feb 24.

[30] Huang C, Wang Y, Li X, Ren L, Zhao J, Hu Y, Zhang L, Fan G, Xu J, Gu X, Cheng Z. Clinical features of patients infected with 2019 novel coronavirus in Wuhan, China. The Lancet. 2020 Feb 15;395(10223):497-506.

[31] Dong E, Du H, Gardner L. An interactive web-based dashboard to track COVID-19 in real time. The Lancet infectious diseases. 2020 Feb 19.

[32] Ruan Q, Yang K, Wang W, Jiang L, Song J. Clinical predictors of mortality due to COVID-19 based on an analysis of data of 150 patients from Wuhan, China. Intensive care medicine. 2020 Mar 3:1-3.

[33] Xiong Y, Sun D, Liu Y, Fan Y, Zhao L, Li X, Zhu W. Clinical and High-Resolution CT Features of the COVID-19 Infection: Comparison of the Initial and Follow-up Changes. Investigative radiology. 2020 Mar 3.

[34] Surveillances V. The epidemiological characteristics of an outbreak of 2019 novel coronavirus diseases (COVID-19)-China, 2020. China CDC Weekly. 2020;2(8):113-22.

[35] Adhikari SP, Meng S, Wu YJ, Mao YP, Ye RX, Wang QZ, Sun C, Sylvia S, Rozelle S, Raat H, Zhou H. Epidemiology, causes, clinical manifestation and diagnosis, prevention and control of coronavirus disease (COVID-19) during the early outbreak period: a scoping review. Infectious diseases of poverty. 2020 Dec;9(1):1-2.

[36] Gautret P, Lagier JC, Parola P, Meddeb L, Mailhe M, Doudier B, Courjon J, Giordanengo V, Vieira VE, Dupont HT, Honoré S. Hydroxychloroquine and azithromycin as a treatment of COVID-19: results of an open-label non-randomized clinical trial. International journal of antimicrobial agents. 2020 Mar 20:105949.

[37] World Health Organization. Novel Coronavirus ( 2019-nCoV): situation report-1. https://www.who.int/docs/defaultsource/coronaviruse/situation-reports/20200121-sitrep-1-2019-ncov.pdf?sfvrsn=20a99c10_4.

[38] WHO Timeline - COVID-19. https://www.who.int/news-room/detail/08-04-2020-who-timeline---covid-19.

[39] Shi H, Han X, Jiang N, Cao Y, Alwalid O, Gu J, Fan Y, Zheng C. Radiological findings from 81 patients with COVID-19 pneumonia in Wuhan, China: a descriptive study. The Lancet Infectious Diseases. 2020 Feb 24.

[40] Wu P, Hao X, Lau EH, Wong JY, Leung KS, Wu JT, Cowling BJ, Leung GM. Real-time tentative assessment of the epidemiological characteristics of novel coronavirus infections in Wuhan, China, as at 22 January 2020. Eurosurveillance. 2020 Jan 23;25(3):2000044.

[41] Wang W, Xu Y, Gao R, Lu R, Han K, Wu G, Tan W. Detection of SARS-CoV-2 in different types of clinical specimens. Jama. 2020 Jan 1

[42] Yu P, Zhu J, Zhang Z, Han Y. A familial cluster of infection associated with the 2019 novel coronavirus indicating possible person-toperson transmission during the incubation period. The Journal of infectious diseases. 2020 Feb 18.

[43] Guarner J. Three emerging coronaviruses in two decades: the story of SARS, MERS, and now COVID-19.2020.

[44] How China's "Bat Woman" Hunted Down Viruses from SARS to the New Coronavirus. https://www.scientificamerican.com/article/how-chinas-bat-woman-hunted-down-viruses-from-sars-to-the-new-coronavirus1/.

[45] Okada P, Buathong R, Phuygun S, Thanadachakul T, Parnmen S, Wongboot W, Waicharoen S, Wacharapluesadee S, Uttayamakul S, Vachiraphan A, Chittaganpitch M. Early transmission patterns of coronavirus disease 2019 (COVID-19) in travellers from Wuhan to Thailand, January 2020. Eurosurveillance. 2020 Feb 27;25(8):2000097. 
[46] Outbreak of acute respiratory syndrome associated with a novel coronavirus, China: first local transmission in the EU/EEA - third update. https://www.ecdc.europa.eu/sites/default/files/documents/novel-coronavirus-risk-assessment-china-31-january-2020_0.pdf.

[47] Sahin AR, Erdogan A, Agaoglu PM, Dineri Y, Cakirci AY, Senel ME, Okyay RA, Tasdogan AM. 2019 Novel Coronavirus (COVID19) Outbreak: A Review of the Current Literature. EJMO. 2020;4(1):1-7.

[48] European Centre for Disease Prevention and Control. https://www.ecdc.europa.eu/en/novel-coronavirus/event-background-2019

[49] Eurosurveillance Editorial Team. Note from the editors: novel coronavirus (2019-nCoV). Eurosurveillance. 2020 Jan $23 ; 25(3): 2001231$.

[50] Zhang T, Wu Q, Zhang Z. Probable pangolin origin of SARS-CoV-2 associated with the COVID-19 outbreak. Current Biology. 2020 Mar 19.

[51] Stefanelli P, Faggioni G, Presti AL, Fiore S, Marchi A, Benedetti E, Fabiani C, Anselmo A, Ciammaruconi A, Fortunato A, De Santis R. Whole genome and phylogenetic analysis of two SARS-CoV-2 strains isolated in Italy in January and February 2020: additional clues on multiple introductions and further circulation in Europe. Eurosurveillance. 2020 Apr 2;25(13):2000305.

[52] Prabakaran P, Xiao X, Dimitrov DS. A model of the ACE2 structure and function as a SARS-CoV receptor. Biochemical and biophysical research communications. 2004 Jan 30;314(1):235-41.

[53] Singhal T. A review of coronavirus disease-2019 (COVID-19). The Indian Journal of Pediatrics. 2020 Mar 13:1-6.

[54] Read JM, Bridgen JR, Cummings DA, Ho A, Jewell CP. Novel coronavirus 2019-nCoV: early estimation of epidemiological parameters and epidemic predictions. MedRxiv. 2020 Jan 1.

[55] Backer JA, Klinkenberg D, Wallinga J. Incubation period of 2019 novel coronavirus (2019-nCoV) infections among travellers from Wuhan, China, 20-28 January 2020. Eurosurveillance. 2020 Feb 6;25(5):2000062.

[56] Bastola A, Sah R, Rodriguez-Morales AJ, Lal BK, Jha R, Ojha HC, Shrestha B, Chu DK, Poon LL, Costello A, Morita K. The first 2019 novel coronavirus case in Nepal. The Lancet Infectious Diseases. 2020 Mar 1;20(3):279-80.

[57] Mizumoto K, Kagaya K, Zarebski A, Chowell G. Estimating the asymptomatic proportion of coronavirus disease 2019 (COVID-19) cases on board the Diamond Princess cruise ship, Yokohama, Japan, 2020. Eurosurveillance. 2020 Mar 12;25(10):2000180.

[58] Liu W, Zhang Q, Chen J, Xiang R, Song H, Shu S, Chen L, Liang L, Zhou J, You L, Wu P. Detection of Covid-19 in children in early January 2020 in Wuhan, China. New England Journal of Medicine. 2020 Apr 2;382(14):1370-1.

[59] World Health Organization. Novel Coronavirus ( 2019-nCoV): situation report, 3 . (www.who.ind; healthtopic/coronavirus/laboratorydiagnosticsfornovel coronavirus).

[60] Pneumonia of unknown cause - China. https://www.who.int/csr/don/05-january-2020-pneumonia-of-unkown-cause-china/en/.

[61] Yoo JH, Chung MS, Kim JY, Ko JH, Kim Y, Kim YJ, Kim JM, Chung YS, Kim HM, Han MG, Kim SY. Report on the Epidemiological Features of Coronavirus Disease 2019 (COVID-19) Outbreak in the Republic of Korea from January 19 to March 2 , 2020.

[62] Holshue ML, DeBolt C, Lindquist S, Lofy KH, Wiesman J, Bruce H, Spitters C, Ericson K, Wilkerson S, Tural A, Diaz G. First case of 2019 novel coronavirus in the United States. New England Journal of Medicine. 2020 Mar 5; 382(10): 929-936.

[63] Wang C, Horby PW, Hayden FG, Gao GF. A novel coronavirus outbreak of global health concern. The Lancet. 2020 Feb $15 ; 395(10223): 470-3$.

[64] Li G, Fan Y, Lai Y, Han T, Li Z, Zhou P, Pan P, Wang W, Hu D, Liu X, Zhang Q. Coronavirus infections and immune responses. Journal of medical virology. 2020 Apr;92(4):424-32.

[65] Statement on the meeting of the International Health Regulations (2005) Emergency Committee regarding the outbreak of novel coronavirus (2019-nCoV). https://www.who.int/news-room/detail/23-01-2020-statement-on-the-meeting-of-the-international-healthregulations-(2005)-emergency-committee-regarding-the-outbreak-of-novel-coronavirus-(2019-ncov).

[66] Nacoti M, Ciocca A, Giupponi A, Brambillasca P, Lussana F, Pisano M, Goisis G, Bonacina D, Fazzi F, Naspro R, Longhi L. At the epicenter of the Covid-19 pandemic and humanitarian crises in Italy: changing perspectives on preparation and mitigation. NEJM Catalyst Innovations in Care Delivery. 2020 Mar 21;1(2).

[67] Paules CI, Marston HD, Fauci AS. Coronavirus infections-more than just the common cold. Jama. 2020 Feb 25;323(8):707-8.

[68] Wei WE. Presymptomatic Transmission of SARS-CoV-2-Singapore, January 23-March 16, 2020. MMWR. Morbidity and Mortality Weekly Report. 2020;69.

[69] Wei WE, Li Z, Chiew CJ, Yong SE, Toh MP, Lee VJ. Presymptomatic Transmission of SARS-CoV-2 - Singapore, January 23-March 16, 2020. Morbidity and Mortality Weekly Report. 2020 Apr 10;69(14):411.

[70] World Health Organization. Advice on the use of masks in the context of COVID-19: interim guidance, 6 April 2020. World Health Organization; 2020.

[71] Stoecklin SB, Rolland P, Silue Y, Mailles A, Campese C, Simondon A, Mechain M, Meurice L, Nguyen M, Bassi C, Yamani E. First cases of coronavirus disease 2019 (COVID-19) in France: surveillance, investigations and control measures, January 2020. Eurosurveillance. 2020 Feb 13;25(6):2000094.

[72] Lancet T. Emerging understandings of 2019-nCoV. Lancet (London, England). 2020 Feb 1;395(10221):311.

[73] Huang C, Wang Y, Li X, Ren L, Zhao J, Hu Y, Zhang L, Fan G, Xu J, Gu X, Cheng Z. Clinical features of patients infected with 2019 novel coronavirus in Wuhan, China. The Lancet. 2020 Feb 15;395(10223):497-506.

[74] Kumar D, Malviya R, Sharma PK. Corona Virus: A Review of COVID-19. Eurasian Journal of Medicine and Oncology. 2020;4:8-25.

[75] Li S, Wang Y, Xue J, Zhao N, Zhu T. The impact of COVID-19 epidemic declaration on psychological consequences: a study on active weibo users. International journal of environmental research and public health. $2020 \mathrm{Jan} ; 17(6): 2032$.

[76] Cambodia Confirms First Case of Coronavirus -Health Minister. https://www.usnews.com/news/world/articles/2020-01-27/cambodiaconfirms-first-case-of-coronavirus-health-minister.

[77] Rothe C, Schunk M, Sothmann P, Bretzel G, Froeschl G, Wallrauch C, Zimmer T, Thiel V, Janke C, Guggemos W, Seilmaier M. Transmission of 2019-nCoV infection from an asymptomatic contact in Germany. New England Journal of Medicine. 2020 Mar 5;382(10):970-1.

[78] Tang B, Bragazzi NL, Li Q, Tang S, Xiao Y, Wu J. An updated estimation of the risk of transmission of the novel coronavirus (2019nCov). Infectious disease modelling. 2020 Jan 1;5:248-55

[79] Eurosurveillance Editorial Team. Note from the editors: World Health Organization declares novel coronavirus (2019-nCoV) sixth public health emergency of international concern. Eurosurveillance. 2020 Feb 6;25(5):200131e.

[80] Gupta R, Pandey G, Chaudhary P, Pal SK. SEIR and Regression Model based COVID-19 outbreak predictions in India. medRxiv. 2020 Jan 1.

[81] Singh J, Singh J. COVID-19 and its impact on society. Electronic Research Journal of Social Sciences and Humanities. 2020 Apr 3;2.

[82] Mukhtar F, Mukhtar N. CORONAVIRUS (COVID-19): LET'S PREVENT NOT PANIC. Journal of Ayub Medical College Abbottabad. 2020 Feb 21;32(1)

[83] Dahl E. Coronavirus (Covid-19) outbreak on the cruise ship Diamond Princess. International Maritime Health. 2020;71(1):5-8. 
[84] Yuen KS, Ye ZW, Fung SY, Chan CP, Jin DY. SARS-CoV-2 and COVID-19: The most important research questions. Cell Biosci. 2020; 10: 40 .

[85] Coronavirus: First death outside China reported in Philippine. https://www.bbc.com/news/world-asia-51345855.

[86] Lescure FX, Bouadma L, Nguyen D, Parisey M, Wicky PH, Behillil S, Gaymard A, Bouscambert-Duchamp M, Donati F, Le Hingrat Q, Enouf V. Clinical and virological data of the first cases of COVID-19 in Europe: a case series. The Lancet Infectious Diseases. 2020 Mar 27.

[87] Lai CC, Shih TP, Ko WC, Tang HJ, Hsueh PR. Severe acute respiratory syndrome coronavirus 2 (SARS-CoV-2) and corona virus disease-2019 (COVID-19): the epidemic and the challenges. International journal of antimicrobial agents. $2020 \mathrm{Feb}$ 17:105924.

[88] Wang LF, Shi Z, Zhang S, Field H, Daszak P, Eaton BT. Review of bats and SARS. Emerging infectious diseases. 2006 Dec;12(12):1834.

[89] Cheng SC, Chang YC, Chiang YL, Chien YC, Cheng M, Yang CH, Huang CH, Hsu YN. First case of Coronavirus Disease 2019 (COVID-19) pneumonia in Taiwan. Journal of the Formosan Medical Association. 2020 Feb 26.

[90] Li H, Liu SM, Yu XH, Tang SL, Tang CK. Coronavirus disease 2019 (COVID-19): current status and future perspective. International Journal of Antimicrobial Agents. 2020 Mar 29:105951.

[91] Coronavirus disease 2019 (COVID-19) Situation Report - 26. https://www.who.int/docs/default-source/coronaviruse/situationreports/20200215-sitrep-26-covid-19.pdf?sfvrsn=a4cc6787_2.

[92] Coronavirus disease 2019 (COVID-19) Situation Report - 40. https://www.who.int/docs/default-source/coronaviruse/situationreports/20200229-sitrep-40-covid-19.pdf.

[93] Negahdaripour M. The Battle Against COVID-19: Where Do We Stand Now?. Iranian journal of medical sciences. 2020 Mar;45(2):81.

[94] Rota PA, Oberste MS, Monroe SS, Nix WA, Campagnoli R, Icenogle JP, Penaranda S, Bankamp B, Maher K, Chen MH, Tong S. Characterization of a novel coronavirus associated with severe acute respiratory syndrome. science. 2003 May 30;300(5624):1394-9.

[95] Song F, Shi N, Shan F, Zhang Z, Shen J, Lu H, Ling Y, Jiang Y, Shi Y. Emerging 2019 novel coronavirus (2019-nCoV) pneumonia. Radiology. 2020 Apr;295(1):210-7.

[96] Yang Y, Peng F, Wang R, Guan K, Jiang T, Xu G, Sun J, Chang C. The deadly coronaviruses: The 2003 SARS pandemic and the 2020 novel coronavirus epidemic in China. Journal of autoimmunity. 2020 Mar 3:102434.

[97] Rodriguez-Morales AJ, Bonilla-Aldana DK, Balbin-Ramon GJ, Rabaan AA, Sah R, Paniz-Mondolfi A, Pagliano P, Esposito S. History is repeating itself: Probable zoonotic spillover as the cause of the 2019 novel Coronavirus Epidemic. Infez Med. 2020 Mar $1 ; 28(1): 3-5$.

[98] Xu J, Zhao S, Teng T, Abdalla AE, Zhu W, Xie L, Wang Y, Guo X. Systematic comparison of two animal-to-human transmitted human coronaviruses: SARS-CoV-2 and SARS-CoV. Viruses. $2020 \mathrm{Feb} ; 12(2): 244$.

[99] Andersen KG, Rambaut A, Lipkin WI, Holmes EC, Garry RF. The proximal origin of SARS-CoV-2. Nature medicine. 2020 Apr;26(4):450-2.

[100]Koff WC, Williams MA. Covid-19 and Immunity in Aging Populations-A New Research Agenda. New England Journal of Medicine. 2020 Apr 17.

[101]Yang Y, Peng F, Wang R, Guan K, Jiang T, Xu G, Sun J, Chang C. The deadly coronaviruses: The 2003 SARS pandemic and the 2020 novel coronavirus epidemic in China. Journal of autoimmunity. 2020 Mar 3:102434.

[102]Ge XY, Li JL, Yang XL, Chmura AA, Zhu G, Epstein JH, Mazet JK, Hu B, Zhang W, Peng C, Zhang YJ. Isolation and characterization of a bat SARS-like coronavirus that uses the ACE2 receptor. Nature. 2013 Nov;503(7477):535-8.

[103] Sun J, He WT, Wang L, Lai A, Ji X, Zhai X, Li G, Suchard MA, Tian J, Zhou J, Veit M. COVID-19: epidemiology, evolution, and cross-disciplinary perspectives. Trends in Molecular Medicine. 2020 Mar 21.

[104]Cao Y, Li L, Feng Z, Wan S, Huang P, Sun X, Wen F, Huang X, Ning G, Wang W. Comparative genetic analysis of the novel coronavirus (2019-nCoV/SARS-CoV-2) receptor ACE2 in different populations. Cell Discovery. 2020 Feb 24;6(1):1-4.

[105]Lam TT, Shum MH, Zhu HC, Tong YG, Ni XB, Liao YS, Wei W, Cheung WY, Li WJ, Li LF, Leung GM. Identifying SARS-CoV-2 related coronaviruses in Malayan pangolins. Nature. 2020 Mar 26:1-6.

[106] Sanders AJ. Hospitals \& Asylums Novel Coronavirus-Infected Pneumonia Treatment HA-13-3-20 By Anthony J. Sanders The coronavirus has caused the stock market to panic, and self and mandatory quarantines are restricting global travel, work and school. As of March 6, 2020 more than 100,000 people have been.

[107] Yang Y, Peng F, Wang R, Guan K, Jiang T, Xu G, Sun J, Chang C. The deadly coronaviruses: The 2003 SARS pandemic and the 2020 novel coronavirus epidemic in China. Journal of autoimmunity. 2020 Mar 3:102434.

[108] Yang Y, Islam MS, Wang J, Li Y, Chen X. Traditional Chinese medicine in the treatment of patients infected with 2019-new coronavirus (SARS-CoV-2): a review and perspective. International journal of biological sciences. 2020;16(10):1708.

[109]Lu G, Wang Q, Gao GF. Bat-to-human: spike features determining 'host jump'of coronaviruses SARS-CoV, MERS-CoV, and beyond. Trends in microbiology. 2015 Aug 1;23(8):468-78.

[110] Chatterjee P, Nagi N, Agarwal A, Das B, Banerjee S, Sarkar S, Gupta N, Gangakhedkar RR. The 2019 novel coronavirus disease (COVID-19) pandemic: A review of the current evidence. The Indian Journal of Medical Research. 2020 Mar 30.

[111]Coronavirus disease 2019 (COVID-19) Situation Report - 41. https://www.who.int/docs/default-source/coronaviruse/situationreports/20200301-sitrep-41-covid-19.pdf?sfvrsn=6768306d 2.

[112]Coronavirus disease 2019 (COVID-19) Situation Report - 42. https://www.who.int/docs/default-source/coronaviruse/situationreports/20200302-sitrep-42-covid-19.pdf?sfvrsn=224c1add 2 .

[113] Origins of SARS-CoV-2 - natural or man-made? https://www.news-medical.net/news/20200330/Origins-of-SARS-CoV-2-natural-orman-made.aspx

[114]Andersen KG, Rambaut A, Lipkin WI, Holmes EC, Garry RF. The proximal origin of SARS-CoV-2. Nature medicine. 2020 Apr; 26(4):450-2.

[115] Shereen MA, Khan S, Kazmi A, Bashir N, Siddique R. COVID-19 infection: origin, transmission, and characteristics of human coronaviruses. Journal of Advanced Research. 2020 Mar 16.

[116]CoronaVirus likely of animal origin, no sign of lab manipulation: WHO https://epaper.timesgroup.com/Olive/ODN/TimesOfIndia/Default.aspx

[117]Chinese Officials Blame US Army for Coronavirus. https://www.the-scientist.com/news-opinion/chinese-officials-blame-us-army-forcoronavirus-67267.

[118]Nobel winning scientist claims Covid-19 virus was man-made in Wuhan lab. https://www.livemint.com/news/world/nobel-winningscientist-claims-covid-19 virus-was-man-made-in-wuhan-lab-11587303649821.html.

[119]Guan WJ, Ni ZY, Hu Y, Liang WH, Ou CQ, He JX, Liu L, Shan H, Lei CL, Hui DS, Du B. Clinical characteristics of 2019 novel coronavirus infection in China. MedRxiv. 2020. 
[120] Tavakoli A, Vahdat K, Keshavarz M. Novel Coronavirus Disease 2019 (COVID-19): An Emerging Infectious Disease in the 21st Century. ISMJ. 2020 Jan 10;22(6):432-50.

[121]Bai Y, Yao L, Wei T, Tian F, Jin DY, Chen L, Wang M. Presumed asymptomatic carrier transmission of COVID-19. Jama. 2020 Feb 21.

[122] Surveillances V. The epidemiological characteristics of an outbreak of 2019 novel coronavirus diseases (COVID-19) - China, 2020. China CDC Weekly. 2020;2(8):113-22.

[123] Kucharski AJ, Russell TW, Diamond C, Liu Y, Edmunds J, Funk S, Eggo RM, Sun F, Jit M, Munday JD, Davies N. Early dynamics of transmission and control of COVID-19: a mathematical modelling study. The lancet infectious diseases. $2020 \mathrm{Mar} 11$.

[124] Rothan HA, Byrareddy SN. The epidemiology and pathogenesis of coronavirus disease (COVID-19) outbreak. Journal of autoimmunity. 2020 Feb 26:102433.

[125] Scientists Probe How Coronavirus Might The The https://www.npr.org/sections/goatsandsoda/2020/04/03/825639323/scientists-probe-how-coronavirus-might-travel-through-the-air.

[126] Yeo C, Kaushal S, Yeo D. Enteric involvement of coronaviruses: is faecal-oral transmission of SARS-CoV-2 possible?. The Lancet Gastroenterology \& Hepatology. 2020 Apr 1;5(4):335-7.

[127]van Doremalen N, Bushmaker T, Morris DH, Holbrook MG, Gamble A, Williamson BN, Tamin A, Harcourt JL, Thornburg NJ, Gerber SI, Lloyd-Smith JO. Aerosol and surface stability of SARS-CoV-2 as compared with SARS-CoV-1. New England Journal of Medicine. 2020 Mar 17.

[128]Bushmaker T, Morris DH, Holbrook MG, Gamble A, Williamson BN, Tamin A, Harcourt JL, Thornburg NJ, Gerber SI, Lloyd-Smith JO, Munster VJ. Aerosol and Surface Stability of SARS-CoV-2 as Compared with SARS-CoV-1. The New England journal of medicine. 2020 Mar.

[129] Xu Z, Shi L, Wang Y, Zhang J, Huang L, Zhang C, Liu S, Zhao P, Liu H, Zhu L, Tai Y. Pathological findings of COVID-19 associated with acute respiratory distress syndrome. The Lancet respiratory medicine. 2020 Apr 1;8(4):420-2.

[130]Fang Y, Zhang H, Xie J, Lin M, Ying L, Pang P, Ji W. Sensitivity of chest CT for COVID-19: comparison to RT-PCR. Radiology. 2020 Feb 19:200432.

[131]Zhou F, Yu T, Du R, Fan G, Liu Y, Liu Z, Xiang J, Wang Y, Song B, Gu X, Guan L. Clinical course and risk factors for mortality of adult inpatients with COVID-19 in Wuhan, China: a retrospective cohort study. The Lancet. 2020 Mar 11.

[132] Jiang F, Deng L, Zhang L, Cai Y, Cheung CW, Xia Z. Review of the clinical characteristics of coronavirus disease 2019 (COVID-19). Journal of General Internal Medicine. 2020 Mar 4:1-5.

[133] Chen H, Guo J, Wang C, Luo F, Yu X, Zhang W, Li J, Zhao D, Xu D, Gong Q, Liao J. Clinical characteristics and intrauterine vertical transmission potential of COVID-19 infection in nine pregnant women: a retrospective review of medical records. The Lancet. 2020 Mar 7;395(10226):809-15.

[134]Chen T, Wu D, Chen H, Yan W, Yang D, Chen G, Ma K, Xu D, Yu H, Wang H, Wang T. Clinical characteristics of 113 deceased patients with coronavirus disease 2019: retrospective study. Bmj. 2020 Mar 26;368.

[135] How patients recover from Covid-19 - Times of India. https://timesofindia.indiatimes.com/how-patients-recover-from-covid19/articleshow/75193901.cms.

[136]Lan L, Xu D, Ye G, Xia C, Wang S, Li Y, Xu H. Positive RT-PCR test results in patients recovered from COVID-19. Jama. 2020 Feb 27.

[137]Phua J, Weng L, Ling L, Egi M, Lim CM, Divatia JV, Shrestha BR, Arabi YM, Ng J, Gomersall CD, Nishimura M. Intensive care management of coronavirus disease 2019 (COVID-19): challenges and recommendations. The Lancet Respiratory Medicine. 2020 Apr 6. https://doi.org/10.1016/S2213-2600(20)30161-2.

[138]Kolifarhood G, Aghaali M, Saadati HM, Taherpour N, Rahimi S, Izadi N, Nazari SS. Epidemiological and clinical aspects of Covid19; a narrative review. Archives of Academic Emergency Medicine. 2020;8(1).

[139] Jiang F, Deng L, Zhang L, Cai Y, Cheung CW, Xia Z. Review of the clinical characteristics of coronavirus disease 2019 (COVID-19). Journal of General Internal Medicine. 2020 Mar 4:1-5.

[140]Zhao D, Yao F, Wang L, Zheng L, Gao Y, Ye J, Guo F, Zhao H, Gao R. A comparative study on the clinical features of COVID-19 pneumonia to other pneumonias. Clinical Infectious Diseases. 2020 Mar 12.

[141] Wang Y, Wang Y, Chen Y, Qin Q. Unique epidemiological and clinical features of the emerging 2019 novel coronavirus pneumonia (COVID-19) implicate special control measures. Journal of medical virology. 2020 Mar 5.

[142]Zimmermann P, Curtis N. Coronavirus Infections in Children Including COVID-19: An Overview of the Epidemiology, Clinical Features, Diagnosis, Treatment and Prevention Options in Children. The Pediatric infectious disease journal. 2020 May;39(5):355.

[143] Qiu H, Wu J, Hong L, Luo Y, Song Q, Chen D. Clinical and epidemiological features of 36 children with coronavirus disease 2019 (COVID-19) in Zhejiang, China: an observational cohort study. The Lancet Infectious Diseases. 2020 Mar 25.

[144] Hormati A, Shahhamzeh A, Afifian M, Khodadust F, Ahmadpour S. Can COVID-19 present unusual GI symptoms?. Journal of Microbiology, Immunology, and Infection. 2020 Mar 21.

[145]https://www.timesofisrael.com/israeli-company-hopes-to-treat-coronavirus-patients-with-placenta-cells/

[146]https://scrip.pharmaintelligence.informa.com/SC142067/Can-Placenta-Cells-Save-Severe-COVID19-Patients

[147] https://www.lifecell.in/corona-virus-awareness.

[148]https://www.bloomberg.com/news/videos/2020-04-16/holy-name-medical-center-uses-placenta-cells-to-treat-covid-19-video

[149]B'Luru firm seeks nod to test stem cell drug. https://epaper.timesgroup.com/Olive/ODN/TimesOfIndia/Default.aspx

[150]COVID-19 relapse: Three theories can explain worrying trend [ https:/www.downtoearth.org.in/news/health/covid-19-relapse-threetheories-can-explain-worrying-trend-70364]

[151]Italian scientists claim to have developed vaccine that neutralises coronavirus in human cells [https:/www.cnbctv18.com/healthcare/coronavirus-cure-italy-claims-worlds-first-covid-19-vaccine-report-5850281.htm]

[152]A COVID-19 treatment inspired by llamas.[https:/www.fiercebiotech.com/research/a-covid-19-treatment-inspired-by-1lamas]

[153]Heartburn Pill in Short Supply After Word of Covid-19 Trial. [https://www.bloomberg.com/news/articles/2020-05-04/heartburn-pill-inshort-supply-after-word-of-covid-19-trial] 